\author{
Doi 10.5943/ppq/7/1/9 \\ Copyright $\odot$ Mushroom Research Foundation
}

\title{
Field evaluation of beneficial and deleterious effects of rhizobacteria on cotton stand and yield
}

\author{
Aly A.A. ${ }^{1}$, Gomaa E.Z. ${ }^{2 *}$, Ashour ${ }^{1}$, S.M.E., Zayed A.Z. ${ }^{1}$ and Mostafa M.A. ${ }^{1}$ \\ ${ }^{1}$ Plant Pathology Research Institute, Agricultural Research Center, Giza, Egypt \\ ${ }^{2}$ Department of Biological and Geological Sciences, Faculty of Education, Ain Shams University, Cairo, Egypt
}

Aly AA, Gomaa EZ, Ashour SME, Zayed AZ, Mostafa MA 2017 - Field evaluation of beneficial and deleterious effects of rhizobacteria on cotton stand and yield. Plant Pathology \& Quarantine 7(1), 71-80, Doi 10.5943/ppq/7/1/9

\begin{abstract}
Thirteen Bacillus strains, one Lactibacillus strain, and two Pseudomonas strains were isolated from the rhizosphere of cotton seedlings collected at various locations in Egypt. Three field trials were conducted at Sakha (North Delta Region), El-Gemmeiza (Middle Delta Region), and Sirs ElLian (Middle Delta Region) in 2015 to evaluate the beneficial and deleterious effects of rhizobacteria on cotton stand and yield. Field evaluation revealed inconsistent performance among strains from one site to another. Thus, while certain strains effectively controlled seedling dampingoff at some locations, they were ineffective in controlling the disease at other locations or even increased disease. Seedling stand counts were not correlated with seed cotton yield at Sakha and ElGemmeiza, while they were highly correlated at Sirs El-Lian. Regarding each of seedling stand counts (survival) and yield, the performance of the tested strains at any site was not correlated with their performance at the other two sites. Grouping the strains by cluster analysis based on their effect patterns was neither related to their taxonomic position nor to geographic origins. Of the 16 strains, strain no. 10 of Bacillus circulans is a promising strain for commercialization for two reasons: firstly, it significantly increased stand at all sites and secondly, it significantly increased seed cotton yield at Sirs El-Lian.
\end{abstract}

Key words - cotton - rhizobacteria - stand - yield

\section{Introduction}

Cotton seedling damping-off is caused by a complex of seed-borne and soil-inhabiting organisms. These organisms are found in all cotton producing areas of Egypt. Although the populations of inciting organisms differ from area to area, the pathogens most commonly involved in the disease complex are Rhizoctonia solani and Fusarium spp. (El-Samawaty et al. 1999). The disease occurs as pre-germination decay of the seed, decay of the seedling on the way to the soil surface (pre-emergence damping-off), partial or complete girdling of the emerged seedling at or near the soil surface ("sore shine" or post-emergence damping-off), and seedling root rot (Watkins et al. 1981).

Cotton seedling damping-off is difficult to control due to the broad host range of the pathogens involved in the disease, and long viability of their resting structures. Commercially 
acceptable resistant cultivars are unavailable in Egypt. Large-scale application of solarization and fumigation to reduce resting structures in soil is expensive and difficult to achieve. Thus, the widespread use of seed-dressing fungicides for controlling the disease has become indispensable under Egyptian conditions. While effective fungicides are available (Abdel-Aziz et al. 1996, ElSamawaty et al. 1999), it is becoming increasingly evident that their widespread use is associated with some problems, such as the potential harmful effect on non-target organisms, the development of resistant races of the pathogens, and possible carcinogenicity. Other problems include gradual elimination and phasing out of some compounds (Zaki et al. 1998). Therefore, rhizobacteriamediated biological control has become a promising alternative for controlling the disease.

Bacillus spp. and Pseudomonas spp. have been widely used for biological control of cotton seedling damping-off because of their rapid growth rate and their ability to colonize rhizospheres and spermospheres (Ardakani 2009, 2010, Mansoori 2013, Khiyami et al. 2014). Bacillus is a Gram-positive aerobic endospore forming genus. Endospore forming, universally found in the genus is thought to be a strategy for survival in the soil, wherein these bacteria predominate and endospores make them resistant to unfavorable environmental conditions (Kumar et al. 2012). Pseudomonas infests the rhizosphere abundantly and aggressively colonizes plant roots (Elliott \& Lynch 1984). The relatively rapid growth rate of Pseudomonas spp. and the selectivity of roots, due to the high affinity of Gram-negative bacteria for amino acid exudates, give Pseudomonas a greater rhizosphere competence than other rhizosphere microflora (Azad et al. 1985).

In general, rhizobacteria, in particular Bacillus and Pseusomonas, antagonize phytopathogenic fungi through various mechanisms such as competition for niches (e.g. iron through siderophores synthesis); parasitism, that may involve production of hydrolytic enzymes such as chitinase, $\beta$-1,3-glucanase, protease, and cellulase, that lyse fungus cell walls; inhibition of the pathogen by secreting antimicrobial compounds such as antibiotics, toxins, and biosurfactants; and induction of systemic resistance in host plants (Mavrodi 2006, Kumar et al. 2012).

Lactic acid bacteria (LAB) such as Lactobacillus amylovorus have previously been shown to play a crucial role in the preservation and microbial safety of food because of their beneficial influence on nutritional and shelf-life characteristics, and are naturally occurring in many food systems (Guo et al. 2014). Few studies have been aimed at antifungal activity of LAB against phytopathogenic fungi, e.g., citrus fungal pathogens Geotrichum citriaurantii (Gerez et al. 2010) and the potato late blight pathogen Phytophthora infestans (Guo et al. 2014).

Contrary to common belief that Bacillus and Pseudomonas are effective biocontrol agents, among members of these two genera are numerous species that are pathogenic to plants (Peng et al. 2013). In addition to the pathological effects, some Bacillus spp. and Pseudomonas spp. may be involved in deleterious synergistic interactions with phytopathogenic fungi, particularly rootinvading fungi. The objective of the present study was to evaluate the beneficial and deleterious effects of rhizobacteria on cotton stand and yield under field conditions.

\section{Materials \& Methods}

\section{Bacterial strains}

Sixteen bacterial strains were randomly selected from the bacterial culture collection of Cotton Diseases Research Section, Plant Pathology Research Institute, Agriculture Research Center, Giza, Egypt. All strains were originally isolated from the rhizosphere of cotton seedlings collected in various locations in Egypt (Table 1).

\section{Preparation of bacterial inoculum}

Bacterial strains were grown in nutrient glucose broth at $30^{\circ} \mathrm{C}$ for $72 \mathrm{~h}$ on a shaker. The growth was adjusted turbidimetrically to $10^{8} \mathrm{cfu} / \mathrm{ml}$ using spectro $2000 \mathrm{RSP} 220 \mathrm{v}$. 50Hz. Bacterial cultures were formulated in powder form by mixing $400 \mathrm{ml}$ of cell suspension with $1 \mathrm{~kg}$ talc as carrier, which previously had been autoclaved for $30 \mathrm{~min}$. over two successive days, $10 \mathrm{~g}$ of carboxy methylcellulose (CMC) was added to $1 \mathrm{~kg}$ of the carrier and mixed well. The $\mathrm{pH}$ of all 
materials was adjusted to 7.0 by adding calcium carbonate. The bacterial population was assessed as $4 \times 10^{7} \mathrm{cfu} / \mathrm{g}$ talc.

\section{Field trials}

The strains evaluation trials were conducted in 2015 growing season at the agricultural research stations of Sakha (North Delta), El-Gemmeiza (Middle Delta), and Sirs El-Lian (Middle Delta). Soil type was clay in all the experimental sites. Each experiment was designed as a randomized complete block of three replicates, each replicate consisted of two, $5 \mathrm{~m}$ rows. Each row included 25 hills, each contained 10 seeds. Cotton (Gossypium barbadense L.) cultivars (Table 3) were chosen according to the recommendations of each experimental station. Slightly moist seeds were treated with the powdered inoculum of each strain at a rate pf $10 \mathrm{~g} / \mathrm{kg}$ seeds, and thoroughly shaken in plastic bags for $5 \mathrm{~min}$. and allowed to dry for 2 hours before being planted. Planting dates were 12 April in Sakha, 31 March in El-Gemmeiza, and 24 March in Sirs El-Lian. Stands (healthy surviving seedlings) were recorded 45 days from sowing. Seed cotton yield (cottonseed and lint before ginning) was picked from 15-30 October at each site.

\section{Isolation and identification of fungi in soils of the experimental sites}

Infected seedlings, which showed typical damping-off symptoms, were removed from the field and washed under tap water to remove any adhering soil. Small pieces of necrotic root and hypocotyle tissue were surface sterilized with $10 \%$ Clorox solution for $2 \mathrm{~min}$. and washed several times with sterilized water. The surface sterilized pieces were then dried on sterilized filter papers and plated on potato dextrose agar (PDA) medium amended with streptomycin sulfate and rose bengal to eliminate bacterial contaminations. The plates were incubated at $26 \pm 3^{\circ} \mathrm{C}$ for 3-7 days. The developing colonies were identified according to Gilman (1966), Barnet \& Hunter (1979). Colonies of each fungus were expressed as percentage of the total developing colonies.

\section{Statistical analysis of the data}

The experimental design was a randomized complete block with three replicates. Least significant difference (LSD) was used to compare treatment means. Analysis of variance (ANOVA) was carried out by MSTAT-C statistical package. Data from each field site were subjected to ANOVA independently because of differences in environmental conditions and site management. Correlation and cluster analyses were performed with the software package SPSS 10.0 .

\section{Results}

Identification of the selected strains (Table 1) revealed that 13 strains $(81.3 \%)$ belonged to genus Bacillus, two strains (12.5\%) belonged to genus Pseudomonas, and only one strain (6.3\%) belonged to genus Lactobacillus. B. subtilis was represented by four (25\%) strains, B. circulans, $B$. coagulants, and B. cereus were each represented by two strains (12.5\%). B. globisprus and B. pumilus were each represented by only one strain (6.5\%). Species of Bacillus strain no. 5 was unidentified.

Nine of the strains $(56.3 \%)$ were isolated from the Nile Delta governorates (Daqahliya, Sharqiya, Qualyubiya, Beheira and Minufiya), four strains (25\%) from Middle Egypt governorates (Giza and Minia), one strain (6.3\%) from Upper Egypt (Assiute governorates), and two strains $(12.5 \%)$ from unknown origins. Bacillus strains were isolated from widely separated governorates in Nile Delta, Middle Egypt, and Upper Egypt, while Pseudomonas strains were restricted to Nile Delta.

The infected seedlings used in isolation yielded Fusarium spp. and unidentified fungi at all the experimental sites, while they yielded any of the other fungi at only two sites. The difference in isolation frequency between Fusarium spp. and any of the other fungi was significant only in ElGemmeiza (Table 2). 
Certain strains did effectively control seedling damping-off at some locations (Table 3); however, there was a lack of consistency among locations, that is, they were ineffective in controlling the disease at other locations or even increased the disease. For example, strains no. 2, 4, 13, and 16 significantly increased the disease at Sakha, suppressed it at El-Gemmeiza, and had no effect on it at Sirs El-Lian. Strains no. 9, 11, and 14 had no effect on the disease at Sakha, while they suppressed it in El-Gemmeiza and Sirs El-Lian. Strain no. 10 was the only strain, which effectively controlled the disease in the three experimental sites. None of the tested strains failed in controlling the disease at all the sites. Only one strain (6.3\%) effectively controlled the disease at Sakha, 15 strains $(93.8 \%)$ at El-Gemmeiza, and six strains (37.5\%) at Sirs El-Lian.

Table 1 Identification and geographic origins of bacterial strains isolated from rhizosphere of cotton seedlings.

\begin{tabular}{llll}
\hline Strain No. & \multicolumn{1}{c}{ Classification } & \multicolumn{2}{c}{ Geographic origin } \\
Governorate & \multicolumn{1}{c}{ Region } \\
\hline 1 & Bacillus coagulans & Unknown & Unknown \\
2 & B. globisporus & Daqahliya & East Delta \\
3 & B. pumilus & Giza & Middle Egypt \\
4 & Lactobacillus amylovorus & Sharqiya & East Delta \\
5 & Bacillus sp. & Qualyubiya & South Delta \\
6 & B. subtilis & Assiute & Upper Egypt \\
7 & B. subtilis & Minya & Middle Egypt \\
8 & B. circulans & Beheira & West Delta \\
9 & B. coagulans & Sharqiya & East Delta \\
10 & B. circulans & Beheira & West Delta \\
11 & B. subtilis & Minya & Middle Egypt \\
12 & B. cereus & Unknown & Unknown \\
13 & B. subtilis & Sharqiya & East Delta \\
14 & B. cereus & Giza & Middle Egypt \\
15 & Pseudomonas putida & Minufiya & Middle Delta \\
16 & P. fluorescens & Daqahliya & East Delta \\
\hline
\end{tabular}

Table 2 Frequency of fungi isolated from cotton seedlings infected with post-emergence dampingoff in the experimental sites.

\begin{tabular}{llll}
\hline \multicolumn{1}{c}{ Fungus } & \multicolumn{1}{c}{$\begin{array}{c}\text { Sakha } \\
\text { (cv. Giza 86) }\end{array}$} & $\begin{array}{c}\text { Isolation frequency (\%) } \\
\text { El-Gemmeiza } \\
\text { (cv. Giza 89) }\end{array}$ & $\begin{array}{c}\text { Sirs El-Lian } \\
\text { (cv. Giza 89) }\end{array}$ \\
\hline Fusarium spp. & 20.82 & 52.96 & 27.50 \\
Rhizoctonia solani & 12.50 & 17.06 & 0.00 \\
Alternaria spp. & 0.00 & 6.68 & 21.66 \\
Aspergillus spp. & 26.26 & 0.00 & 10.00 \\
Rhizopus spp. & 40.40 & 0.00 & 16.68 \\
Unidentified & 33.36 & 13.34 & 10.07 \\
\hline
\end{tabular}

Colonies of each fungus are expressed as percentage of the total developing colonies. Each value is the mean of 5 replications (plates).

$\operatorname{LSD}(\mathrm{p}=0.05)$ for fungus $\times$ experimental site $=29.79$. 
Table 3 Effects of treating cotton seeds with bacterial strains on surviving seedlings and yield under field conditions in 2015.

\begin{tabular}{|c|c|c|c|c|c|c|c|}
\hline \multirow[t]{2}{*}{ No. } & \multirow[t]{2}{*}{ Treatment } & \multicolumn{2}{|c|}{ Sakha (Giza 86) } & \multicolumn{2}{|c|}{$\begin{array}{c}\text { El-Gemmeiza } \\
(\text { Giza 89) }\end{array}$} & \multicolumn{2}{|c|}{$\begin{array}{l}\text { Sirs El-Lian } \\
\text { (Giza 89) }\end{array}$} \\
\hline & & $\begin{array}{c}\text { Survival } \\
(\%)\end{array}$ & $\begin{array}{c}\text { Yield } \\
\left(\text { Kentaraa }^{\mathrm{a}}\right. \\
\left.\text { Feddan }^{\mathrm{b}}\right)\end{array}$ & $\begin{array}{c}\text { Survival } \\
(\%)\end{array}$ & $\begin{array}{c}\text { Yield } \\
\text { (Kentar/ } \\
\text { Feddan) }\end{array}$ & $\begin{array}{c}\text { Survival } \\
(\%)\end{array}$ & $\begin{array}{c}\text { Yield } \\
\text { (Kentar/Fedd } \\
\text { an) }\end{array}$ \\
\hline 1 & $\begin{array}{l}\text { Bacillus } \\
\text { coagulans }\end{array}$ & 52.60 & 3.04 & 46.67 & 9.75 & $68.33 *(+)$ & 10.84 \\
\hline 2 & B. globisporus & $47.00 *(-)$ & 3.49 & $48.42 *(+)$ & 9.75 & 66.67 & 9.86 \\
\hline 3 & B. pumilus & 48.50 & 2.91 & $49.58 *(+)$ & 11.29 & 63.33 & 9.10 \\
\hline 4 & L. amylovorus & $44.60 *(-)$ & $1.98 *(-)$ & $61.17 *(+)$ & 11.29 & 66.67 & 10.15 \\
\hline 5 & Bacillus sp. & 47.70 & $1.83 *(-)$ & $57.25 *(+)$ & 9.75 & 63.33 & 10.37 \\
\hline 6 & B. subtilis & 47.50 & $2.35 *(-)$ & $48.58 *(+)$ & 11.29 & 61.67 & $8.57 *(-)$ \\
\hline 7 & B. subtilis & $46.80 *(-)$ & $2.37 *(-)$ & $51.00 *(+)$ & 10.60 & $55.00 *(-)$ & $5.70 *(-)$ \\
\hline 8 & B. circulans & $44.85^{*}(-)$ & 2.72 & $51.25 *(+)$ & 7.95 & $58.33 *(-)$ & $7.35^{*}(-)$ \\
\hline 9 & B. coagulans & 51.00 & $2.22 *(-)$ & $59.92 *(+)$ & 10.09 & $71.67 *(+)$ & $11.61 *(+)$ \\
\hline 10 & B. circulans & $55.40 *(+)$ & 2.81 & $48.75 *(+)$ & 9.66 & $68.33 *(+)$ & $11.38 *(+)$ \\
\hline 11 & B. subtilis & 55.20 & 2.74 & $51.67 *(+)$ & 8.98 & $70.00 *(+)$ & 10.19 \\
\hline 12 & B. cereus & 50.50 & 3.64 & $53.25 *(+)$ & 10.26 & $56.67 *(-)$ & $6.63 *(-)$ \\
\hline 13 & B. subtilis & $46.00 *(-)$ & 2.85 & $55.25 *(+)$ & 8.89 & 65.00 & 10.47 \\
\hline 14 & B. cereus & 48.35 & $2.62 *(-)$ & $52.22 *(+)$ & 10.06 & $90.00 *(+)$ & $15.90 *(+)$ \\
\hline 15 & $\begin{array}{l}\text { Pseudomonas } \\
\text { putida }\end{array}$ & $43.25 *(-)$ & 3.39 & $57.00 *(+)$ & 9.24 & $70.00 *(+)$ & 9.99 \\
\hline 16 & P. fluorescens & $40.35^{*}(-)$ & $4.11 *(+)$ & $50.92 *(+)$ & 8.81 & 66.67 & 9.99 \\
\hline 17 & Control $1^{\mathrm{c}}$ & 51.25 & 3.17 & 45.17 & 10.60 & 63.33 & 10.05 \\
\hline \multirow[t]{2}{*}{18} & Control $2^{\mathrm{d}}$ & 37.60 & 2.24 & 45.67 & 7.10 & 28.33 & 1.49 \\
\hline & LSD $(p \leq 0.05)$ & 4.05 & 0.55 & 3.08 & 1.06 & 4.08 & 1.28 \\
\hline
\end{tabular}

Strains no. 4 and 5 reduced yield at Sakha, while they had no effect on yield at the other two sites. Isolates no. 6 and 7 significantly reduced yield at Sakha and Sirs El-Lian, while they had no effect on yield at El-Gemmeiza. Isolates no. 9, 10 and 14 increased yield in Sirs El-Lian. Isolates no. 9 and 14 showed deleterious effects on yield at Sakha and had no effect on yield at ElGemmeiza. Isolate no. 10 had no effect on yield at Sakha and yield was not affected by any strain at El-Gemmeiza. Isolate no. 16 was the only isolate which significantly increased yield at Sakha. Regardless of the tested strain, cotton plants produced the lowest seed cotton yield at Sakha due to the high level of late season insect infestation. For all sites combined, 22 biological treatments increased stands; for each individual site the number ranged from one at Sakha to 15 at ElGemmeiza. On the other hand, only four biological treatments increased yield; for each individual site the number ranged from one at Sakha to three at Sirs El-Lian. As to the deleterious effects, 10 biological treatments reduced stands; for each individual site the number ranged from three at Sirs El-Lian to seven at Sakha. Ten biological treatments reduced yield; for each individual site the number ranged from four at Sirs El-Lian to six at Sakha. 
Seedlings stand counts were not correlated with seed cotton yield at Sakha and El-Gemmeiza, while they were highly correlated at Sirs El-Lian (r: 0.956, p=0.000) (Table 4). Regarding each of seedling stand counts (survival) and yield, the performance of tested strains at any site was not correlated with their performance at the other two sites (Table 5).

Five groups of similar strains (strains 3, 6, 2; strains 1, 10, 11; strains 15, 16; strains 9, 13, 5, 8,4 and strains 7,12 ) were identified by cluster analysis (Fig.1). The effect patterns of strains 4 and 14 were quite different from the others. Grouping the strains by cluster analysis was neither related to their taxonomic position nor to geographic origin. For instance, strains 6, 7,11 and 13 belonged to B. subtilis; however, they were placed in remotely related sub-clusters. Another example was strains 1 and 9, which were placed in remotely related sub-clusters although they belonged to $B$. coagulans. Strains 7 and 11 of $B$. subtilis came from Minya, however, they were placed in remotely related sub-clusters. Similarly, strains 8 and 10 of B. circulans were placed in remotely related subclusters although they were isolated from Beheira.

Table 4 Correlation between surviving cotton seedlings and yield under the effects of 16 bacterial strains used for treating seeds in three locations.

\section{Correlation}

\section{Location}

\begin{tabular}{ll}
\hline$-0.223^{\mathrm{a}}(0.406)^{\mathrm{b}}$ & Sakha \\
$0.066(0.807)$ & El-Gemmeiza \\
$0.956(0.000)$ & Sirs El-Lian
\end{tabular}

${ }^{a}$ Linear correlation coefficient, which measures the degree of association between the surviving seedlings and yield.

${ }^{\mathrm{b}}$ probability level and $\mathrm{n}=16$

Table 5 Correlation between effects of locations on the performance of 16 bacterial strains used for treating cotton seeds.

\begin{tabular}{lllc}
\hline \multicolumn{1}{c}{ Variable } & \multicolumn{1}{c}{ Location } & \multicolumn{1}{c}{ Location } \\
\hline Survival & 1- Sakha & \multicolumn{1}{c}{$\mathbf{1}$} \\
& 2- El-Gemmeiza & $-0.273^{\mathrm{a}}(0.306)^{\mathrm{b}}$ & \\
& 3- Sirs El-Lian & $0.147(0.586)$ & $0.111(0.681)$ \\
Yield & 1- Sakha & & \\
& 2- El-Gemmeiza & $-0.382(0.145)$ & $-0.062(0.821)$ \\
& 3- Sirs El-Lian & $-0.120(0.658)$ & - \\
& &
\end{tabular}

a Linear correlation coefficient, which measures the degree of association between effects of two locations on the performance of the bacterial strains.

$\mathrm{b}$ probability level and $\mathrm{n}=16$

\section{Discussion}

Successful application of rhizobacteria for control of cotton seedling damping-off requires development of a delivery system in which the bacteria can survive for a considerable length of time, and development of a suitable method of application to control early and late stages of disease development.

Previous studies demonstrated the successful management of various plant diseases using talc-based bioformulation of rhizobacteria (Manikandan et al. 2010). Talc formulations of sporeforming strains of Bacillus have an advantage over the non-spore forming strains such as Pseudomonas (formulated as vegetative cells). Spores are more robust and resistant to the elevated temperature and high concentrations of chemicals. Moreover, the shelf-life of biological products based on Bacillus spores can survive up to 1-3 years. A disadvantage of the use of spores is that 
after application they need time to return to the metabolic active stage of vegetative cell (Kumar et al. 2012).

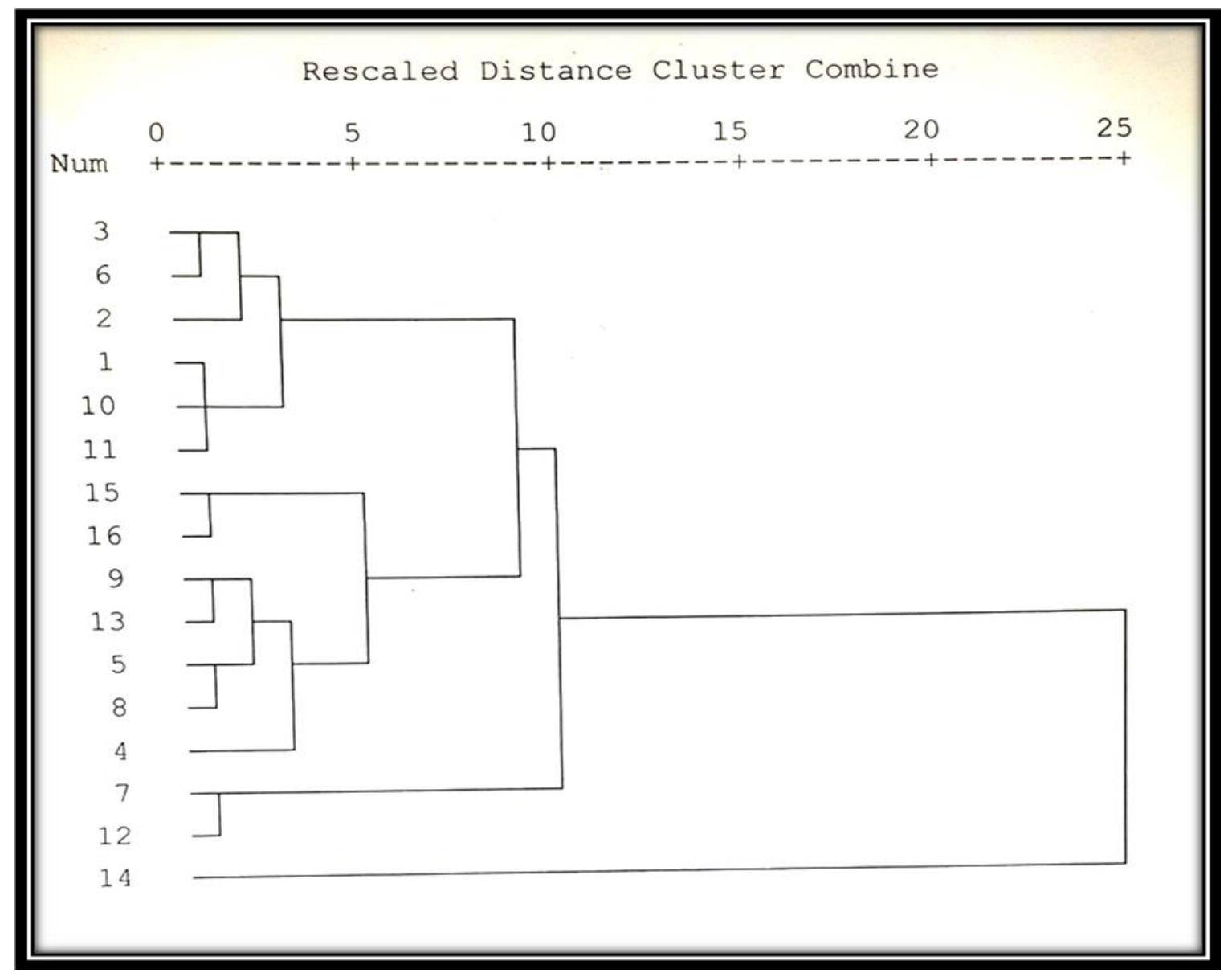

Fig 1 - Phenogram based on average linkage cluster analysis of beneficial and deleterious effects of 16 rhizobacterial strains on cotton stand and yield under field conditions at three experimental sites. The tested strains were Bacillus coagulans (1), B. globisporus (2), B. pumilus (3), Lactobacillus amylovorus (4), Bacillus sp. (5), B. subtilis (6), B. subtilis (7), B. circulans (8), B. coagulans (9), B. circulans (10), B. subtilis (11), B. cereus (12), B. subtilis (13), B. cereus (14), Pseudomonas putida (15), and P. fluorescens (16).

In the present study, talc and CMC-based powder formulation of bacterial strains was used as a delivery system and seed treatment was used as a delivery system that is, the powder formulation was used for treating seeds. When treated seeds were sown in soil, the bacteria moved from spermosphere to rhizosphere and established there; in other words, bacterial strains colonized the rhizosphere at the time of seed germination. Once a portion of root was occupied by the introduced bacteria, the native bacteria in soil were unable to displace them (Vidhyasekaran \& Muthamilan 1995). The establishment of the introduced bacteria in the rhizosphere of plants is due to an improved capacity to compete for root exudates (Gamliel \& Katan 1992).

It is worth noting that the talc (magnesium silicate) and CMC-based powder formulation in itself, and regardless of any beneficial effects of the introduced strains, significantly increased stand and yield. It seems reasonable to relate these increases to the positive benefits that magnesium and silicon brought to cotton (Kirkpatrick \& Rothrock 2001, Polanco et al. 2014).

The infected seedlings used in isolation yielded Fusarium spp. and Rhizoctonia solani, which are considered major causes of cotton seedling damping-off, while the other isolated fungi are considered minor disease agents except when the cotton seedlings are weakened (Watkins 1981). 
The disease pressures at the experimental sites were due to the pathological effects of the isolated fungi. Plant stands of control 2 (untreated seed) provided the basis for disease pressure estimates, which were high at Sirs El-Lian, moderate at Sakha, and low at El-Gemmeiza.

The results of the present study showed that the performance of the tested strains was sitespecific. Thus, for all sites combined, 48 biological treatments were evaluated as to their beneficial or deleterious effects on stand and yield. Twenty-two (45.83\%) treatments showed beneficial effects on stand. Most of the beneficial treatments (15 treatments) were observed at El-Gemmeiza probably due to the low disease pressure at this site. On the other hand, the relatively high disease pressure at Sakha and Sirs El-Lian may obscure any potential antagonism by the treatments.

Iron availability in soil is inversely correlated with $\mathrm{pH}$ (Misaghi et al. 1998). The $\mathrm{pH}$ of the Egyptian soils range from 7.92 to 9.15 (Aly \& Kandil 1999). In these alkaline soils, iron is expected to be sparingly soluble and too low in concentration to support microbial growth. Thus, it seems reasonable to speculate that siderophore-mediated iron deprivation may be the operative mechanism of damping-off suppression at least by some of the beneficial (antagonistic) treatments. However, one should keep in mind that the extent of disease suppression as a consequence of bacterial siderophore production is affected by several factors including the specific pathogen, the specific bacteria, the soil type, the crop, and the affinity of the siderophore for iron (Bashan \& deBashan 2005).

Chitin is a major structural component of most fungal cell walls (Sahai \& Manocha 1993). Various species of Bacillus have been shown to secrete chitinase, including B. circulans, B. licheniformis, B. cereus, and some others (Pleban et al. 1997). Moreover, there is a wealth of data supporting the important role of chitinolytic enzymes in bacterium-fungus antagonistic interactions (Haran et al. 1996). The chitinase exhibited activity over the $\mathrm{pH}$ range of 4.5-7.5 (Pleban et al. 1997). Therefore, it is unlikely that chitinase played an important role in the successful antagonism exhibited by the beneficial strains because the range of $\mathrm{pH}$ values in the Egyptian soils is unfavorable for its activity.

It is noteworthy that strain no. 10 was the only strain, which was effective in increasing stand at all sites. It seems that this strain had some type of stable mechanism(s) for repressing the disease. From practical stand point, strain no. 10 seems to be a promising strain for commercialization for two reasons; firstly, it significantly $(\mathrm{p} \leq 0.05)$ increased stand at all sites and secondly, it significantly $(p \leq 0.05)$ increased seed cotton yield at Sirs El-Lian. However, this will require more comprehensive evaluation at as many sites as possible.

Ten $(20.83 \%)$ of the biological treatments showed deleterious effects on stand (significantly reduced survival). These deleterious treatments could be due to the deleterious rhizobacteria (DRB) that affect plants by their metabolites without parasitizing plant tissues (Schippers et al. 1987). Fluorescent and nonfluorescent pseudomonads as well as Bacillus spp. among rhizobacteria conform to this definition (Suslow et al. 1982). DRB induce growth retardation, root discoloration, wilting, necrotic reactions, distortions of leaves and roots, or stunting of plants (Schippers et al. 1987). Increase in the susceptibility of plants to parasitic pathogens is another possible mode of action by which DRB exert their detrimental effects on stand and yield (Schippers et al. 1987). However, one should keep in mind that the deleterious synergistic interactions between rhizobacteria and root-invading fungi are not simple or universal phenomena. Pathogen - bacteria compatability may be an important factor in determining the outcome of the interaction between rhizobacteria and fungi pathogenic on cotton seedlings (Aly et al. 1996).

The deleterious effects of rhizobacteria on cotton stand were also reported under field conditions in natural soil (Hagedorn et al. 1993) and under greenhouse conditions in autoclaved soil (Khiyami et al. 2014).

The incidence of damping-off of cotton seedlings traditionally has been attributed to fungal infections, and the pathogenicity of several fungi has been demonstrated (Watkins et al. 1981). To our knowledge, no attempts have been made to identify organisms other than fungi, and usually bacteria that are detected are treated as contaminants. We believe that rhizobacteria can play a synergistic role in cotton damping-off disease, and it is likely that with more comprehensive 
isolation, a greater involvement of rhizobacteria in cotton damping-off disease will be demonstrated.

Sixteen $(33.33 \%)$ of the biological treatments had no effect on stand. A key factor involved in this lack of success in biocontrol activity could be a rapid decline of the size of populations of active cells, to levels ineffective to achieve antagonism following introduction into soil. This rapid decline (microbiostasis) occurs when the introduced bacterial strains are unable to cope with the adverse and fluctuating biotic and abiotic soil conditions, to survive, and to remain active. For instance, declines were observed for newly introduced population of typical soil bacteria such as fluorescent pseudomonads and B. subtilis (Veen et al. 1997). The lack of correlation between seedling stand counts and seed cotton yield at Sakha and El-Gemmeiza, after the application of rhizobacteria, was also observed by Hagedorn et al. (1993) and Aly et al. (2000).

\section{References}

Abdel-Aziz MA, Moustafa SM, Ismail AA. 1996 - Impact of imidacloprid insecticide on efficiency of some fungicides in controlling damping-off and root rot disease of cotton seedlings. Journal of Agriculture Research Tanta University 22, 243-255.

Aly AA, El-Samman MG, Hussein EM, Zayed SM. 2000 - Use of Pseudomonas fluorescens to suppress damping-off of cotton seedlings. Mansoura University Journal of Agricultural Sciences 25, 2031-2040.

Aly AA, Kandil NF. 1999 - Effect of physical and chernical edaphic factors on incidence of cotton seedling disease and on frequencies of fungi isolated from infected seedlings. Mansoura University Journal of Agricultural Sciences 24, 4701-4715.

Aly AA, Tawfik AE, Afify AH. 1996 - Effect of rhizobacteria on susceptibility of cotton seedlings to Sclerotium rolfsii and Rhizoctonia solani. Mansoura University Journal of Agricultural Sciences 21, 241-249.

Ardakani SS, Heydari A, Khorasani N, Arjmandi R. 2010 - Development of new bioformulations of Pseudomonas fluorescens and evaluation of these products against damping-off of cotton seedlings. Journal of Plant Pathology 92, 83-88.

Ardakani SS, Heydari A, Khorasani NA, Arjmandi R, Ehteshami M. 2009 - Preparation of new biofungicides using antagonistic bacteria and mineral compounds for controlling cotton seedling damping-off disease. Journal of Plant Protection Research 49, 49-55.

Azad HR, Davis JR, Schnathorst WC, Kado CI. 1985 - Relationships between rhizoplane and rhizosphere bacteria and Verticillium wilt resistance in potato. Archives of Microbiology 140, 347-351.

Barnett HL, Hunter BB. 1979 - Illustrated Genera of Imperfect Fungi, $3^{\text {rd }}$ ed. Burgess Publishing Company, Minneapolis, Minnesota, 241.

Bashan Y, de-Bashan LF. 2005 - Plant growth promoting bacteria. pp. 103-115. In, Encyclopedia of Soil in the Environment. Vol. 1, D. Hillel, ed. Elsevier, Oxford, U.K.

El-Samawaty AMA. 1999 - Studies on cotton root rot disease. MSc. Thesis, Assuit University, Assuit, pp.108.

Elliot IF, Lynch JM. 1984 - Pseudomonas as a factor in the growth of winter wheat, Triticum aestivum L. Soil Biology and Biochemistry 16, 69-71.

Gamliel A, Katan J. 1992 - Chemotaxis of fluorescent Pseudomonads towards seed exudates and germinating seeds in solarized soil. Phytopathology Journal 82, 328-332.

Gerez CL, Carbajo MS, Rollan G, Torres Leal G, de Valdez F. 2010 - Inhibition of citrus fungal pathogens by using lactic acid bacteria. Journal of Food Science 75, 354-359.

Gilman JC 1966 - A Manual of Soil Fungi, $2^{\text {nd }}$ ed. The Iowa State University Press, Iowa, pp. 450.

Guo J, Brosnan B, Furey A, Arendt EK, Axel C, Coffey A. 2014 - Anti-oomycete potential of Lactobacillus omylovorus JG2 against the potato blight pathogen Phytophthora infestans. International Journal of Current Microbiology and Applied Science 3, 630-647. 
Hagedorn C, Gould WD, Bardinelli TR. 1993 - Field evaluation of bacterial inoculants to control seedling disease pathogens of cotton. Plant Diseases 278-282.

Haran S, Schikler H, Chet I. 1996 - Molecular mechanisms of lytic enzymes involved in the biocontrol activity of Trichoderma harzianum. Microbiology 142, 2321-2331.

Khiyami MA, Omar MR, Abd-Elsalam KA, Aly AA. 2014 - Bacillus-based biological control of cotton seedling disease complex. Journal of Plant Protection Research 54, 340-348.

Kirkpatrick TL, Rothrock CS. 2001 - Compendium of Cotton Disease, $2^{\text {nd }}$ ed. The American Phytopathological Society, Saint Paul, Minnesota p.77.

Kumar P, Khare S, Dubey RC. 2012 - Diversity of Bacilli from disease suppressive soil and their role in plant growth promotion and yield enhancement. New York Science Journal 5, 90-111.

Manikandan R, Saravanakumar D, Rajendran L, Raguchander T, Samiyappan R. 2010 Standardization of liquid formulation of Pseudomonas fluorescens PF1 for its efficiency against Fusarium wilt of tomato. Biological Control 54, 83-89.

Mansoori M, Heydari A, Hassanzadeh N, Rezaee S, Naraghi L. 2013 - Evaluation of Pseudomonas and Bacillus bacterial antagonists for biological control of cotton Verticillium wilt disease. Journal of Plant Protection Research 53, 154-157.

Mavrodi DV, Blankenfeldt W, Thomashow LS. 2006 - Phenazine compounds in fluorescent Pseudomonas spp. biosynthesis and regulation. Annual Review of Phytopathology 44, 417445.

Misaghi IJ, Olsen MW, Cotty PJ, Donndelinger CR. 1988 - Fluorescent siderophore-mediated iron deprivation. A contingent biological control mechanism. Soil Biology and Biochemistry 20, 573-574.

Peng Q, Yuan Y, Gao M. 2013 - Bacillus pumilus, a novel ginger rhizome rot pathogen in China. Plant Diseases 97, 1308-1315.

Pleban S, Chernin L, Chet I. 1997 - Chitinolytic activity of an endophytic strain of Bacillus cereus. Letters in Applied Microbiology 25, 284-288.

Polanco LR, Rodrigues FA, Moreira EN, Duarte HSS, Cacique IS, Valente LA, Vieira RF, Paula Junior TJ, Vale FXR. 2014 - Management of anthracnose in common bean by foliar sprays of potassium silicate, sodium molybdate, and fungicides. Plant Diseases 98, 84-89.

Sahai AS, Manocha MS. 1993 - Chitinase of fungi and plants, their involvement in morphogenesis and host-parasite interaction. FEMS Microbiology Review 11, 317-338.

Schippers B, Bakker AW, Bakker PA. 1987 - Interactions of deleterious and beneficial rhizosphere microorganisms and the effect of cropping practices. The Annual Review of Phytopathology $25,339-358$.

Suslow TV. 1982 - Role of root - colonizing bacteria in plant growth. pp. 187-223. In: Phytopathogenic Prokaryotes. Vol. 1, M.S. Mount and G.H. Lacey, eds. Academic Press, New York.

Veen JAV, Van Overbeek LS, Van Elsas JD. 1997 - Fate and activity of microorganism introduced into soil. Microbiology and Molecular Biology Review 61, 121-135.

Vidhyasekaran P, Muthamilan M. 1995 - Development of formulations of Pseudomonas fluorescens for control of chickpea wilt. Plant Diseases 79, 782-786.

Watkins GM 1981 - Compendium of Cotton Diseases. The American Phytopathological Society, Saint Paul, Minnesota, pp. 87.

Zaki K, Misaghi IJ, Heydari A, Shatla MN. 1998 - Control of cotton seedling damping-off in the field by Burkholderia, Pseudomonas cepacia. Plant Disease 82, 291-293. 